\title{
Assessment of genotypic and phenotypic variability, heritability and genetic advance for seed yield and related agronomic traits in faba bean (Vicia faba L.) genotypes in the Northern State, Sudan
}

\author{
Fatih E. A. Hamza ${ }^{1}$, Gamal E. Khalifa ${ }^{2}$ and Amin Al Sir Ahmed ${ }^{3 *}$ \\ ${ }^{1}$ Merowe Research Station, Agricultural Research Corporation, P. O. Box 126 Wad Medani, Sudan. \\ ${ }^{2}$ Hudeiba Research Station, Agricultural Research Corporation, P. O. Box 126 Wad Medani, Sudan. \\ ${ }^{3}$ Damazin Research Station, Agricultural Research Corporation, P. O. Box 126 Wad Medani, Sudan.
}

Accepted 30 March, 2017

\begin{abstract}
A study was conducted at Merowe Research Station Farm, Northern state of Sudan, during two successive winter seasons 2010/11 and 2011/2012. Genotypic and phenotypic coefficient of variation, heritability and genetic advance were determined for yield and its contributing parameters in 12 faba bean genotypes. Data were gathered on the seed yield $\left(\mathrm{kg} \mathrm{ha}^{-1}\right)$ and some yield related traits: days to $50 \%$ flowering, days to $90 \%$ maturity, plant height $(\mathrm{cm})$, number of pods/plant, number of seeds/pod and 100-seed weight $(\mathrm{g})$. Analysis of variance for traits studied showed significant differences among genotypes, seasons and their interaction $(P$ $\leq 0.01$ ) for most of the studied traits. High phenotypic coefficient of variation (PCV) was observed for number of pods/plant and 100 - seed weight. Medium PCV was observed for plant height and days to $50 \%$ flowering. High genotypic coefficients of variation (GCV) were observed for plant height and 100 - seed weight. Moderate genotypic coefficients of variation were estimated for days to $50 \%$ flowering and number of pods/plant. Phenotypic coefficient of variation values for most characters was closer to the corresponding genotypic coefficient of variation values showing little environment effect on the expression of these characters. The estimated values of broad-sense heritability were found to be between $57.97 \%$ for $100-$ seed weight and $1.87 \%$ for number of pods per plant. High heritability indicated that selection based on mean would be successful in improving these traits. Genetic grains that expected from selecting the top 5\% of the genotypes, as a present of mean were varied from $0.65 \%$ for plant height to $8.45 \%$ for 100 - seed weight.
\end{abstract}

Keywords: Faba bean, variability, heritability, genetic advance, seed yield.

*Corresponding author. E-mail: aminalnosh@yahoo.com.

\section{INTRODUCTION}

Faba bean (Vicia faba L.) is a significant crop worldwide, ranking fourth important grain pulse after dry beans, dry peas and chickpeas (Hawtin and Stewart, 1979) and second popular food legume in Europe (Picard et al., 1988). The bean is a common breakfast meal in the Mediterranean region, Central and East Asia, and Ethiopia, and a familiar crop in the Americas and Oceania
(Bond et al., 1985). Broad beans are the most favored food legume in Sudan (Salih and Ali, 1989).

World production has varied during the past 10 years ranging from a low of 3.58 million tons in 997/98 to a high of 4.85 million tons in 2002/03, trending upward (FAO, 2004).

Faba bean is the most important food legume in Sudan 
(Osman et al., 2010a, b). It is the main staple food and the main source of protein for millions of people. Its nutritional importance is even greater as many people have limited access to animal food protein. Its consumption increased among the middle and low income strata of the population, being the traditional dish for breakfast and supper. Further demand has, however, increased over time in the whole country to magnitudes that increasing productivity would be essential to satisfy local needs.

Faba beans are traditionally grown in the fertile (Gureir) soils, which are silty loams deposited in a narrow strip along the banks of the Nile and on isolated islands. Due to the scarcity of fertile soil and the high demand for Faba bean coupled with the ever increasing prices, nontraditional lands of inferior quality such as 'karu' and 'high terrace' soils are coming up into production.

Selection of superior genotypes based on the yield alone is less efficient due to the complexity of the yield and its dependence on its components (Sindhu et al., 1985). Direct selection was also ineffective due to the large genotype - environment interaction (Yassin, 1973). For a breeding program to be successful there must be genetic differences among the individual plants of the breeder's collection of material. Then the breeder will be able to select the desirable combination of genes. Most desirable traits such as yield, protein content and quality are under the control of many genes and environmental factors. The environment affects the expression of the character and there will be no discrete classes of phenotype and there are continuous variations of this character. Such variations need statistical techniques for their evaluation. This type of character is known as the quantitative character. The situation is different from the character considered by Mendel, the qualitative character. Observed phenotypes can be measured and assessed while the genotypes can be inferred from the phenotype data.

In faba bean, a self pollinated crop, the analyses of variance method can be used to estimate the heritability. The observed mean square will be equated to the expected mean square and the value of phenotypic variance, $\sigma^{2} p$, and genotypic variance, $\sigma^{2} g$, will be obtained from the analyses of variance table. The genetic advance achieved in each breeding cycle depends on how the additive gene effect is beneficial (Hassan, 1991).

The present study aimed to estimate the variability, heritability and genetic advance for yield and yield components of twelve faba bean genotypes.

\section{MATERIALS AND METHODS}

\section{Experimental site}

The data of this research experiment were collected from a study conducted over two consecutive winter seasons (2010/11 and 2011/12), at Merowe (The Experimental Farm of Merowe Research Station of Northern state), which is located at Latitude: $18^{\circ} 27^{\prime} 0^{\prime \prime} \mathrm{N}$,
Longitude: $31^{\circ} 49^{\prime} 59^{\prime \prime}$ E, Elevation: $258 \mathrm{~m}$.

\section{Genetic material}

The genetic material used in this study comprised a total of 12 genotypes of faba bean (Vicia faba L.), which were selected from the national legume breeding program of the Agricultural Research Corporation (ARC), Sudan. Ten genotypes are advanced breeding lines and two released faba bean varieties; Basabeer and Hudeiba 93 were included as checks. Code number and name of the faba bean studied genotypes are given in Table 1.

\section{Cultural practices}

\section{Land preparation}

The field prepared by disk ploughing, harrowing and leveling. After two days from leveling, the land was ridged.

\begin{abstract}
Sowing
The seeds were sown manually on both sides of the ridge in rows, at the rate of two seeds per hole. The plot size was consisted of 5 ridges, $5 \mathrm{~m}$ long spaced $0.6 \mathrm{~m}$. The sowing dates of the two seasons were usually within the third week of November. The plants were irrigated equally at 10 to 12 days interval. The crop took a total of 11 irrigations during the growing period. Nitrogen was added as urea (46\%) at a rate of $43 \mathrm{~kg} \mathrm{~N} / \mathrm{ha}$ in the $3^{\text {rd }}$ week from sowing and weeds populations were kept to a minimum by hand removal during the first month from sowing. In the first and second season, plants were sprayed with (2-dimethoxyphosphorylsulfanyl$\mathrm{N}$-methylacetamide) against the aphid (Aphis fabae sp.), when it appeared in the field.
\end{abstract}

\section{Experimental layout}

The experiments were arranged in a randomized complete block design with three replications.

\section{Observations and measurements}

During the two seasons, observations were taken on ten plants randomly selected in a plot. Data were recorded on the following vegetative and reproductive characters.

\section{Vegetative characters}

(i) Days to $50 \%$ flowering: it was recorded as the number of days from sowing to the date when $50 \%$ of the plants in a plot bore at least one flower.

(ii) Days to $90 \%$ maturity: it was estimated as days from sowing to the date when $90 \%$ of the leaves in the row turned yellow and green pods became black.

(iii) Plant height: it was measured from ground level to the top of the plant at maturity. An average of ten plants was recorded in centimetres $(\mathrm{cm})$.

\section{Reproductive characters}

(i) Number of pods per plant: pods of 5 randomly taken plants were counted to estimate number of pods per plant. 
Table 1. Faba bean genotypes used in the study.

\begin{tabular}{cl}
\hline Entry no. & Cultivar / line \\
\hline 1 & C. $98 / 02$ \\
2 & C. $98 / 8$ \\
3 & C. $1 / 02$ \\
4 & C. $4 / 02$ \\
5 & C. $8 / 02$ \\
6 & C. $9 / 02$ \\
7 & C. $14 / 02$ \\
8 & C. $15 / 02$ \\
9 & C. $19 / 02$ \\
10 & C. $28 / 02$ \\
11 & BB-7 (check) \\
12 & H. 93 (check) \\
\hline
\end{tabular}

(ii) Number of seeds per pod: it was calculated by dividing the total number of seeds per plant (of the sample) by the total number of pods per plant.

(iii) 100 - seed weight $(\mathrm{g})$

Hundred seeds were taken randomly from each plot and weighed using a sensitive balance namely, Sartorius (made in Germany).

(iv) Seed yield $\left(\mathrm{kg} \mathrm{ha}^{-1}\right)$

At maturity, plots were harvested by hand and seed yield $\mathrm{kg} \mathrm{ha}^{-1}$ was determined.

\section{Statistical analysis}

Analysis of variance was performed separately for each season before running the combined analysis. The mean separation was done using Duncan's Multiple Range Test (DMRT) for the different characters. Statistical analysis was carried out using MSTATC program.

\section{Genetic parameters estimates}

Heritability in broad sense $\left(\mathrm{H}^{2}\right)$ was estimated according to Falconer (1989) using Equation 1:

Heritability $\left(\mathrm{H}^{2}\right)=\left(\sigma^{2} \mathrm{~g} / \delta^{2} \mathrm{ph}\right) \times 100$

$\mathrm{H}^{2}$ : Heritability; $\delta^{2} \mathrm{~g}$ : genotypic variance and $\delta^{2} \mathrm{ph}$ : phenotypic variance. Genotypic $\left(\delta^{2} g\right)$ and phenotypic variances $\left(\delta^{2} p h\right)$ were obtained from the analysis of variance table according to Comstock and Robinson (1952) using Equations 2 and 3:

$\delta^{2} g=(M S 1-M S 2) / r \times S$

$\delta^{2} \mathrm{ph}=(\mathrm{MS} 1) / \mathrm{r} \times \mathrm{s}$

Where r: replication, s: season MS1: Mean square for cultivar, MS2: Mean square for genotype $\times$ season.

The mean values were used for genetic analyses to determine Phenotypic Coefficient of Variation (PCV) and Genotypic Coefficient of Variation (GCV), according to Singh and Chaudhury (1985) using Equations 4 and 5:

Phenotypic coefficient of variation $(P C V)=\left(\sqrt{ } \delta^{2} g / \bar{x}\right) \times 100$
Genotypic coefficient of variation $(\mathrm{GCV})=\left(\sqrt{ } \delta^{2} \mathrm{ph} / \overline{\mathrm{x}}\right) \times 100$

Where:

$\delta^{2} \mathrm{~g}=$ genotypic variance

$\delta^{2} \mathrm{ph}=$ phenotypic variance

$\overline{\mathrm{x}}=$ sample mean

Genetic advance (GA) was calculated with the method suggested by Allard (1960) and Singh and Chaudhury (1985) using Equation 6:

$\mathrm{GA}=\mathrm{K} \cdot \sigma \mathrm{ph} \cdot \mathrm{H}^{2}$

Where:

GA: genetic advance

$\mathrm{K}$ : constant $=2.06$ at $5 \%$ selection intensity

$\sigma p h:$ square root of phenotypic variance

$\mathrm{H}^{2}$ : Heritability

$\mathrm{GA}$ as $\%$ of mean $(\mathrm{GAM})=(\mathrm{GA} /$ mean value $) \times 100$

\section{RESULTS AND DISCUSSION}

Mean squares of 7 traits of the twelve faba bean genotypes in the two environments (seasons) are shown in Table 2. There were significant differences among genotypes, seasons and their interaction $(P \leq 0.01)$ for most of the studied traits.

Estimates of phenotypic and genotypic variances, phenotypic coefficient of variance (PCV), genotypic coefficient of variance (GCV), genetic advance (GA), genetic advance as percent of mean (GAM) and broad sense heritability are presented in Table 3. The phenotypic coefficient of variation (PCV) was high for the number of pods per plant $(33.85 \%)$ followed by $100-$ seed weight $(27.08 \%)$. The estimates of PCV were low for days to $90 \%$ maturity (9.42\%), days to $50 \%$ flowering $(8.66 \%)$ and number of seeds per pod $(2.03 \%)$. The genotypic coefficient of variation (GCV) was high for the traits for the plant height $(39.48 \%)$ followed by $100-$ seed weight $(20.58 \%)$. High GCV value of characters suggested the possibility of improving these traits through selection. Similarly, El-Hosary and Nawar (1984) estimated different levels of GCV in faba bean. Moreover, the difference between PCV and GCV for all traits was small and PCV value was greater than GCV for all the characters indicating that these characters were less influenced by environment. A similar result was reported by Ahmad, (2016). High PCV and GCV values were recorded for the trait 100 - seed weight. The estimates of GCV were low for days to $50 \%$ flowering $(6.40 \%)$, followed by number of pods per plant $(4.63 \%)$ and number of seeds per pod (1.17\%). High heritability with moderate GA and high GCV was recorded for the characters seed yield per plot and 100 - seed weight.

Heritability $\left(\mathrm{H}^{2}\right)$ in broad sense estimates were varied from $1.87 \%$ for number of pods per plant to $57.97 \%$ for 100 - seed weight. In earlier studies, high heritability estimates for seed weight (Shukla and Sharma, 1978) were reported. This finding is thus in agreement with the 
Table 2. Mean squares of yield and some yield components for 12 faba bean genotypes grown during two seasons 2010/11 and 2011/12.

\begin{tabular}{|c|c|c|c|c|}
\hline Traits & $\begin{array}{l}\text { Season } \\
(\text { d.f }=2)\end{array}$ & $\begin{array}{l}\text { Genotype } \\
(\text { d.f = 11) }\end{array}$ & $\begin{array}{c}\text { Seas. } x \text { genotype } \\
(\text { d. } f=22)\end{array}$ & $\begin{array}{c}\text { Pooled errol } \\
(\text { d.f }=66)\end{array}$ \\
\hline Days to flowering & $41.194^{* * *}$ & $6.667^{* * *}$ & $1.316^{\star \star}$ & 0.544 \\
\hline Days to maturity & $83.676^{\star \star}$ & $4.138 \mathrm{~ns}$ & $4.969^{*}$ & 3.283 \\
\hline Plant height $(\mathrm{cm})$ & $3283.968^{\star \star \star}$ & $61.109^{*}$ & $49.561 \mathrm{~ns}$ & 41.911 \\
\hline No. of pods/plant & $2113.001^{\star \star \star}$ & $43.611^{*}$ & $40.749^{\star}$ & 23.507 \\
\hline No. of seeds/pod & $0.526^{*}$ & $0.303^{* *}$ & $0.098 \mathrm{~ns}$ & 0.100 \\
\hline 100-seed weight & $15.509 \mathrm{~ns}$ & $65.201^{* * *}$ & $9.934 \mathrm{~ns}$ & 10.288 \\
\hline Seed yield & $10514492.565^{\star \star \star}$ & $344371.976^{*}$ & $166309.000 \mathrm{~ns}$ & 187605.497 \\
\hline
\end{tabular}

${ }^{*},{ }^{* *}$ and ${ }^{* * *}$ Significant at $0.05,0.01$ and 0.001 levels of probability, respectively. ns = non-significant.

Table 3. Estimation of genetic parameters for different quantitative traits in faba bean genotypes grown during two seasons 2010/11 and 2011/2012.

\begin{tabular}{lccccccc}
\hline Traits & $\boldsymbol{\delta}^{2} \mathbf{p h}$ & $\boldsymbol{\delta}^{2} \mathbf{g}$ & $\mathbf{G C V}(\%)$ & $\mathbf{P C V}(\%)$ & $\mathbf{H}^{2}(\%)$ & GA & GAM (\%) \\
\hline Flowering & 1.08 & 0.59 & 6.40 & 8.66 & 54.60 & 1.19 & 3.21 \\
Maturity & - & - & - & - & - & - & - \\
Plant height & 22.45 & 1.28 & 39.48 & 9.42 & 5.70 & 0.55 & 0.65 \\
Pods / plant & 16.50 & 0.31 & 4.63 & 33.85 & 1.87 & 0.15 & 0.76 \\
Seeds / pod & 0.06 & 0.02 & 1.17 & 2.03 & 33.33 & 0.16 & 6.95 \\
100-seed weight & 10.59 & 6.14 & 20.58 & 27.08 & 57.97 & 3.89 & 8.45 \\
Seed yield & 96066.15 & 19784.77 & 1172.15 & 2582.87 & 20.59 & 7.79 & 0.20 \\
\hline
\end{tabular}

$\delta^{2} \mathrm{~g}=$ Genotypic variance, $\delta 2 \mathrm{ph}=$ Phenotypic variance, $\mathrm{PCV}=$ Phenotypic coefficient of variance, GCV = Genotypic coefficient of variance, $\mathrm{H}^{2}=$ Broad sense heritability, $\mathrm{GA}=$ Genetic advance, $\mathrm{GAM}=\mathrm{Genetic}$ advance as percent of mean.

results obtained in the present investigation. The highest estimate of broad sense heritability $\left(\mathrm{H}^{2}\right)$ was followed by days to $50 \%$ flowering $(54.60 \%)$ and number of seeds per pod (33.33\%). Accordingly Bond et al. (1985) confirmed that faba bean genotype determines the number of seeds per plant. Nevertheless (Daur, et al., 2010) found no significant variability of number of seeds per pod between twelve studied faba bean genotypes. On the other hand the low heritability estimates were established for the traits plant height $(5.70 \%)$ and number of pods per plant (1.87\%).

Generally, heritability determines the effectiveness of selection. The effectiveness of selection for a trait depends on the relative importance of the genetic and environmental factors in the expression of phenotypic differences among genotypes in a population (Singh, 1990). The components of yield that were most heritable in this faba bean population were 100 - seed weight and number of seeds per pod. Therefore, the simultaneous selection for these traits could lead to an increase in seed yield. No trait recorded high GAM. The moderate GAM was recorded by 100 - seed weight (8.45\%) and number of seeds per pod $(6.95 \%)$. All other traits recorded the lowest genetic advance as per cent of mean. These results indicated that the environmental factors had a small effect on the inheritance of such traits.

The moderate heritability and the low genetic advance obtained in this study for the seed yield is probably due the epistemic gene action (Kalia and Sood, 2004) so the mass selection may be ineffective in improving the seed yield in these four genotypes.

\section{CONCLUSION}

The mean squares due to seasons were significant for all the traits except 100 - seed weight. The mean squares due to genotypes were highly significant for seed yield, indicating the existence of the sufficient genetic variability for seed yield. Narrow range of variability was detected in the days to $50 \%$ flowering, number of pods per plant and number of seeds per pod in the twelve faba bean genotypes evaluated in the study. Whereas the high genetic coefficient of variation was observed for plant height $(\mathrm{cm})$ followed by 100 - seed weight $(\mathrm{g})$. Heritability of large number of traits was high and moderate. High estimates of heritability indicated that selection based on mean would be successful in improving these traits. High heritability indicate an additive gene action and, hence, possible trait improvement through selection. 


\section{REFERENCES}

Ahmad MSH, 2016. Studies on genetic variability, heritability and genetic advance in segregating generations of faba bean (Vicia faba L.). Middle East J Agric Res, 5(1):82-89.

Allard RW, 1960. Principles of plant breeding. John Wiley and Sons, New York.

Bond DA, Lawes DA, Hawtin GC, Saxena MC, Stephens JS, 1985. Faba bean (Vicia faba L.). In: Grain Legume Crops. Eds Summerfield, R.J. and Roberts, E.H., William Collins and Sons, London, U.K. pp. 199-265.

Comstock RR, Robinson HF, 1952. Genetic parameters, their estimation and significance. Proceedings of the $6^{\text {th }}$ international Grassland Congress. Vol. 1, Nat. publ. Co. Wash., D.C., U.S.A. pp: 248-291.

Daur I, Sepetoğlu H, Marwat KB, Geverek MN, 2010. Nutrient removal, performance of growth and yield of faba bean (Vicia faba L.). Pak J Bot, 42(5): 3477-3484.

El-Hosary AA, Nawar A.A, 1984. Gene effects in field beans (Vicia faba L.) earliness and maturity. Egypt J Genet Cytol, 13: 109-119.

Falconer, D.S, 1989. Introduction to quantitative genetics. (3rd Ed) Logman Scientific and Technical, Logman House, Burnt Mill, Harlow, Essex, England. pp. 187-208.

FAO, 2004. Statistical Yearbook. Vol. no. 2, Rome, Italy.

Hassan AAM, 1991. Fundamentals of plant breeding. Arabic chamber for publication and Distribution, Cairo, Egypt. (In Arabic).

Hawtin G, Stewart R, 1979. The development, production and problems of faba bean (Vicia faba L.) in West Asia and North Africa. Fabis Newsletter, 1:7-9.

Kalia P, Sood S, 2004. Genetic variation and association analyses for pod yield and other agronomic characters in Indian and Himalayan collection of broad bean (Vicia faba L.) SABRO J Breed Genet, 36: 55-61.

Osman AAM, Yagoub SO, Tut OA, 2010a. Performance of faba beans (Vicia faba L.) cultivars grown in new agro-ecological region of Sudan (Southern Sudan). Austr J Basic Appl Sci, 4(11): 5516-552.

Osman AAM, Yagoub SO, Tut OA, 2010b. Seed yielding of faba beans (Vicia faba L.) cultivars grown in Southern Sudan environment (Malakal Locality). Res J Agric Biol Sci, 6(6): 1042-1046.

Picard JJ, Bond DA, Monti L, Steuckardt R, 1988. Production of pea, faba bean and chickpea in Europe.1065-1080. In: R.J. Summerfield (ed.). World Crops: cool season food legumes Kluwer Publishers, Dordrecht, the Netherlands.

Salih HS, Ali AE, 1989. A new faba bean cultivar for the Northern Province of the Sudan. Fabis newsletter. April.

Shukla GP, Sharma RK, 1978. Genetic variability, correlation and path analysis in fenugreek. Indian J Agric Sci, 48: 518-521.

Sindhu JS, Singh OP, Singh KP, 1985. Component analysis of the factors determining grain yield in faba bean (Vicia faba L.) FABIS News Letter ICARDA, Faba bean Information Service, 13:3-5. In Correlation and Path Coefficient Analysis of seed yield components in the Narbon Bean (Vicia narbonensis L.) Yucel et al (2004). Turk J Agric, 28: 371-376.

Singh BD, 1990. Plant Breeding: Priniciples and Methods. Kalyani Publishers, New Delhi, Ludhiana, pp 335-359.

Singh RK, Chaudhary BD, 1985. Biometrical methods in quantitative genetic analysis. Kalyani Publishers, New Delhi, Ludhiana, India. pp. 39-78.

Yassin TA, 1973. Genotypic and phenotypic in faba bean (Vicia faba L.) in the Northern Province of the Sudan. J Agric Sci Cambridge, 80:119-129.
Citation: Hamza FEA, Khalifa GE, Ahmed AA, 2017. Assessment of genotypic and phenotypic variability, heritability and genetic advance for seed yield and related agronomic traits in faba bean (Vicia faba L.) genotypes in the Northern State, Sudan. Net J Agric Sci, 5(2): 48-52. 